\title{
MAG welding process for S700MC steel
}

\author{
B. Szczucka-Lasota, T. Węgrzyn \& B. Łazarz \\ Silesian University of Technology, Gliwice, Poland
}

T. Szymczak

Motor Transport Institute, Warsaw, Poland

A. Jurek

Novar Sp. z o.o., Gliwice, Poland

K.I. Wilczyński

COBRABID Sp. z o.o, Warsaw, Poland

P. Cybulko

MEDGAL Sp. z o.o., Księżyno, Poland

\begin{abstract}
High-strength steel steels (for instance S700MC) are relatively not very well weldable due to the dominant martensitic microstructure. The utmost difficulty in welding these steels is their tendency to crack after welding. Joint strength tensile and NDT (nondestructive tests) tests were mainly carried out as the main investigation. Also bending tests and metallographic microstructure analyses were carried out. The welds were created using MAG welding with various parameters. Paper aims to verify tensile strength of the thinwalled S700MC steel microstructure after welding with base material.
\end{abstract}

\section{INTRODUCTION}

Definition of Smart City was first used by prof. Boyd Cohen from University Del Desarrollo in Santiago de Chile. A smart city is an urban area that uses different types of electronic methods and sensors to collect data (Lai et al. 2020). This includes also data about transportation systems and communication technology, new materials and innovate technology (interestingengineering.com 2018, McLaren \& Agyeman 2015). Prof. Cohen puts especial attention to necessity of using various modern technologies (including welding) to create a Smart City model. In This research area (also called PBO4), high-strength martensitic steels become increasingly used. The weld metal of S700MC (representative of that grade of steels) deposit contains mainly martensite and coarse ferrite while the base material contains mainly martensite, bainite and much more fragmented ferrite. The differences in microstructure affect the mechanical properties of the base material and the joint (Celin \& Burja 2018, Hobbacher 2016, Muszyński \& Mikielewicz, 2017, Hadryś et al. 2016). In the paper it was decided to make joints with different parameters and compare their properties with base material. From an engineering point of view application of various types of steel depends on their mechanical parameters, which follows material behavior in elastic and elastic-plastic states. It is very well known that the proportional limit is related to Hooke's law and is very requested parameter by a lot of engineering groups on designing and modelling different types of components of various branches of industry (Hadryś 2015, Węgrzyn et al. 2019, www.worldautosteel.org, 
Szymczak et al. 2019). Therefore, this parameter has to obviously be determined by material manufacturers. Nevertheless, a lot of material certificates usually report yield point, ultimate tensile strength as well as elongation, indicating a lack of value considered. This parameter is especially important for high-strength steels because of stress range between proportional limit and yield stress is wider than in the case of typical steels, creating a region for initiation of the first permanent deformation. It can be also connected with cracks occurring earlier than the calculations and manufactures indicates (Szymczak et al, 2019). It also plays an important role in the case of welded joints at which weld and HAZ (Heat Affected Zone) are the potential regions for crack occurring. With respect to fatigue durability and engineering efforts determination of a relationship between stress corresponding with mechanical parameters and number of cycles to fracture plays an important role. Therefore, capturing all mechanical parameters associated with tensile characteristic and fatigue test at the values taken is still important and should not be ignored.

\section{MATERIALS AND METHODS}

A butt-welded joints of S700MC (Table 1) steel with a thickness of $3 \mathrm{~mm}$ was made.

The high content of titanium and niobium translates into high strength of the joint. In lowalloy steels, titanium is at the maximum level of $0.003 \%$. Mechanical properties of S700MC steel are presented in Table 2.

The MAG (Metal Active Gas) welding process in the low position (PA) was applied according to the requirements of EN 15614-1 standards. It was decided to produce welds with the use of MAG process testing two various gas mixtures: $\mathrm{Ar}+2 \% \mathrm{O}_{2}$ and $\mathrm{Ar}+18 \% \mathrm{CO}_{2}$. All of the samples were welded with electrode wire UNION X96 (EN ISO 16834-A G 895 M21 $\mathrm{Mn} 4 \mathrm{Ni2}, 5 \mathrm{CrMo}$ ). Chemical composition of the wire is presented in Table 3.

The input energy during the welding of thicker sheets $(3 \mathrm{~mm})$ was below recommended value $4 \mathrm{~kJ} / \mathrm{cm}$. All welding tests were carried out without preheating. Tables 1 and 2 show the chemical composition and respectively mechanical properties used in the S700MC steel tests. The gap between sheets was varied in range $0-3 \mathrm{~mm}$. The correct results were obtained for gap = $1.5 \mathrm{~mm}$ mainly. That case was taken to further tests (Table 4).

A butt-welded joint made of S700MC steel with a thickness of $3 \mathrm{~mm}$ was made. The MAG welding method (135) was used in the flat position (PA) in accordance with the requirements

Table 1. Chemical composition of S700MC steel (SSAB, 2017).

\begin{tabular}{lllllllll}
\hline $\mathrm{C}[\%]$ & $\mathrm{Si}[\%]$ & $\mathrm{Mn}[\%]$ & $\mathrm{P}[\%]$ & $\mathrm{S}[\%]$ & $\mathrm{Al}[\%]$ & $\mathrm{Nb}[\%]$ & $\mathrm{V}[\%]$ & $\mathrm{Ti}[\%]$ \\
\hline 0.12 & 0.10 & 2.10 & 0.025 & 0.010 & 0.015 & 0.09 & $0.20 *$ & 0.15 \\
\hline
\end{tabular}

Table 2. Mechanical properties of S700MC steel, yield stress, ultimate tensile strength (SSAB, 2017).

\begin{tabular}{llll}
\hline $\begin{array}{l}\text { Yield stress [MPa] } \\
\text { min }\end{array}$ & $\begin{array}{l}\text { Ultimate tensile strength }[\mathrm{MPa}] \\
\min \div \max \end{array}$ & $\begin{array}{l}<3[\mathrm{~mm}] \mathrm{A}_{80 \%} \\
\min \end{array}$ & $\begin{array}{l}\geq 3[\mathrm{~mm}] \mathrm{A}_{5 \%} \\
\min \end{array}$ \\
\hline $500-700$ & $750-950$ & 10 & 12 \\
\hline
\end{tabular}

Table 3. Wire UNION X96 - chemical composition (Böhler Welding, 2004).

\begin{tabular}{llllllll}
\hline $\mathrm{C}[\%]$ & $\mathrm{Si}[\%]$ & $\mathrm{Mn}[\%]$ & $\mathrm{P}[\%]$ & $\mathrm{Cr}[\%]$ & $\mathrm{Mo}[\%]$ & $\mathrm{Ni}[\%]$ & $\mathrm{Ti}[\%]$ \\
\hline 0.1 & 0.8 & 1.8 & 0.010 & 0.45 & 0.65 & 2.45 & 0.007 \\
\hline
\end{tabular}


Table 4. Welding parameters of S700MC steel.

\begin{tabular}{llllllll}
\hline $\begin{array}{l}\text { Layers } \\
\text { order }\end{array}$ & $\begin{array}{l}\text { Welding } \\
\text { method }\end{array}$ & $\begin{array}{l}\text { Diameter of the } \\
\text { electrode }[\mathrm{mm}]\end{array}$ & $\begin{array}{l}\text { Current } \\
\text { intensity } \\
{[\mathrm{A}]}\end{array}$ & $\begin{array}{l}\text { Voltage } \\
{[\mathrm{V}]}\end{array}$ & $\begin{array}{l}\text { Welding } \\
\text { speed }[\mathrm{mm} /\end{array}$ & $\begin{array}{l}\text { Input } \\
\text { energy }[\mathrm{kJ} / \\
\mathrm{cm}]\end{array}$ \\
\hline 1 & 135 & 1.0 & 105 & 19 & DC , $+"$ & $300-400$ & below 4 \\
\hline
\end{tabular}

of EN 15614-1. The preparation of material for a single-bead welding. The detailed data of the welding process parameters is given in Table 4.

Once all of the test were performed the following quality control checks were applied: nondestructive and destructive tests. Non-destructive tests included (NDT): Visual testing (VT) and Magnetic-particle testing (MT). The destructive tests included: bending, examination of microstructure digested with Adler reagent using light microscopy (LM) and tensile and fatigue tests.

Determination of mechanical properties of the parent material, as well as its weld, was carried out using 8874 INSTRON servo-hydraulic testing machine, 2620-602 INSTRON extensometer with measuring range of $12.5 \mathrm{~mm}$ and flat mini-specimens having the nominal dimensions in the measuring region as of: $3 \times 4 \mathrm{~mm}$. All specimens were mounted directly in the gripping systems employing upper and lower grips. The quality of the S700MC was determined based on three tensile tests conducted at three different velocity of control signals i.e. displacement, strain and force (stress), using the following values: $1 \mathrm{~mm} / \mathrm{min}, 0.08 \mathrm{~mm} / \mathrm{mm}$, $1400 \mathrm{~N} / \mathrm{min}(178 \mathrm{MPa} / \mathrm{min})$. It was performed taking the fundamental mechanical parameters such as proportional limit, elastic limit, yield stress and ultimate tensile strength. In the general analysis of the weld behaviour the data from the test under the stress signal was taken into account. It was used with respect to determining the mechanical behavior and the weld under signal directly related to the specimen stiffness, which corresponds to its geometry and material type examined.

Assessment of the weld quality was also examined in fatigue tests taking stress values close to ultimate tensile strength (UTS), yield point (YP), elastic limits (EL) and proportional limit (PL). The experiments under cyclic loading were performed at stress ratio $\mathrm{R}=\sigma_{\min } / \sigma_{\max }=0.1$ up to material fracture at a frequency of $10 \mathrm{~Hz}$ using sinusoidal function, where $\sigma_{\min }$ and $\sigma_{\max }$ mean minimum and maximum stress, respectively. This kind of experiment aimed to assess the value of stress at the number of cycles, which connects fatigue limit and comparing the fatigue data with mechanical parameters of the weld from tensile test.

The specimens were selected by means of laser technique using the commercial device named MAZAK STX mark III having the power of $2.5 \mathrm{~kW}$.

\section{RESULTS}

\subsection{The results of non-destructive tests}

Visual inspection of welds was made using standard auxiliary measures, i.e. $\times 3$ loupe, luxmeter with white light $520 \mathrm{Lx}$. It was found that only some of tested joints were made correctly and met the quality requirements, they were characterized by the limit of acceptability " $\mathrm{B}$ " according to PN-EN ISO 5817. Magnetic-particle test of welds was made using the wet method with the following conditions: field strength $3 \mathrm{kA} / \mathrm{m}$, white light $515 \mathrm{Lx}$, temperature $20{ }^{\circ} \mathrm{C}$, MR-76 detection means, MR-72 contrast. Non-destructive test results are presented in Table 5.

\subsection{The data from bending tests}

Then, a bending test was performed only for those samples that passed the NDT test (W3 and W4). Thus, the experiment was carried out only for samples without cracks (with $\mathrm{B}$ acceptability). 
Table 5. Assessment of non-destructive testing of the movable platform joint.

\begin{tabular}{llllll}
\hline $\begin{array}{l}\text { Sample } \\
\text { designation }\end{array}$ & $\begin{array}{l}\mathrm{Gap} \\
{[\mathrm{mm}]}\end{array}$ & $\begin{array}{l}\text { Gas mixture of } \\
\text { argon }\end{array}$ & $\begin{array}{l}\text { Welding } \\
\text { speed } \\
{[\mathrm{mm} / \mathrm{min}]}\end{array}$ & Observation & Acceptability \\
\hline W1 & 2 & $18 \% \mathrm{CO}_{2}$ & 300 & Cracks in the weld & - \\
W2 & 2 & $2 \% \mathrm{O}_{2}$ & 300 & Cracks in the weld & - \\
W3 & 1.5 & $18 \% \mathrm{CO}_{2}$ & 350 & No cracks & B \\
W6 & 1.5 & $2 \% \mathrm{O}_{2}$ & 350 & No cracks & B \\
W5 & 1.5 & $18 \% \mathrm{CO}_{2}$ & 400 & Cracks in the weld & - \\
W6 & 1.5 & $2 \% \mathrm{O}_{2}$ & 400 & Cracks in the weld & - \\
W7 & 2 & $18 \% \mathrm{CO}_{2}$ & 300 & Cracks in the weld & - \\
W8 & 2 & $2 \% \mathrm{O}_{2}$ & 300 & Cracks in the weld & - \\
\hline
\end{tabular}

Table 6. Bending tests results.

\begin{tabular}{lllll}
\hline Sample designation & Deformed side & $\mathrm{a}_{\mathrm{o}} \times \mathrm{b}_{\mathrm{o}}[\mathrm{mm}]$ & Bending angle $\left[^{\circ}\right]$ & Notes \\
\hline W3 & root of weld & $3.0 \times 20.0$ & 180 & no cracks \\
W3 & face of weld & $3.0 \times 20.0$ & 180 & no cracks \\
W4 & root of weld & $3.0 \times 20.0$ & 180 & cracks in the weld \\
W4 & face of weld & $3.0 \times 20.0$ & 180 & cracks in the weld \\
\hline
\end{tabular}

The tests used: sample with a thickness of $a=3 \mathrm{~mm}$, width of the sample $b=20 \mathrm{~mm}$, mandrel $\mathrm{d}=22 \mathrm{~mm}$, spacing of supports $\mathrm{d}+3 \mathrm{a}=31 \mathrm{~mm}$ and the required angle of bending 180 . Five bending test measurements were carried out for each tested joint thickness on the root side and on the face side. The test results are summarized in Table 6. From the analysis of the results presented in Table 6, it follows that gas mixture $\mathrm{Ar}-18 \% \mathrm{CO}_{2}$ is it is more suitable for this welding process.

\subsection{The results from microscopic observation}

Observations of the samples digested in Adler's reagent were carried out on the Reichert Light Microscope (RLM). The examined joints are dominated by a martensitic and ferritic microstructure - Figure 1a shows the microstructure of W3 sample.

\subsection{Responses in tensile test}

Differences between the strength parameters were followed as a key stage for determining variations in the steel behaviour with respect to the material quality, Table 7. As it can be noticed the value of $30 \mathrm{MPa}$ expressed the maximum difference between the values collected at the type of the mechanical parameter. This confirmed the high quality of the material tested as well as its insensitivity to the control signal types.

Beneficial mechanical parameters of the S700MC welded using the Union X96 wire have been confirmed in the tensile test (Figure 2). This was visible by the values of proportional limit (PL), elastic limit (EL), yield stress (YS) and ultimate tensile strength (UTS). They were very close to the same type points of the tensile curve for the parent material. the significant difference was noticed for elongation, which has obtained close to $86 \%$ lower value than in the case of the parent material, Table 8. It can be explained based on the microstructure ingredient i.e. martensite as the dominant element of the welded joint. In addition to martensite with small amount of coarse-grained ferrite was observed. Only in the base metal more fragmented ferrite apart from martensite microstructure is visible (shown in Figure 1b). 
a)

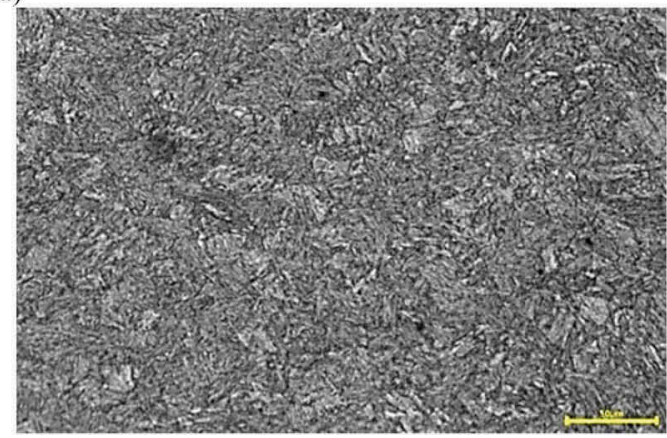

b)

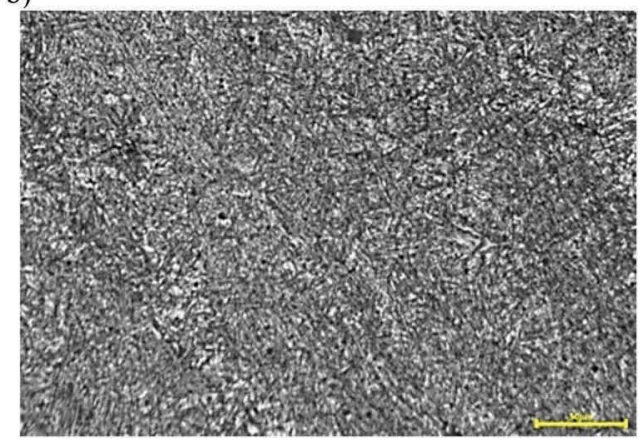

Figure 1. a) Microstructure of the joint (W90). Visible martensite and course ferrite (LM - Light Microscopy), b) Microstructure of the base material. Visible martensite, bainite and fine-grained ferrite (LM).

a)

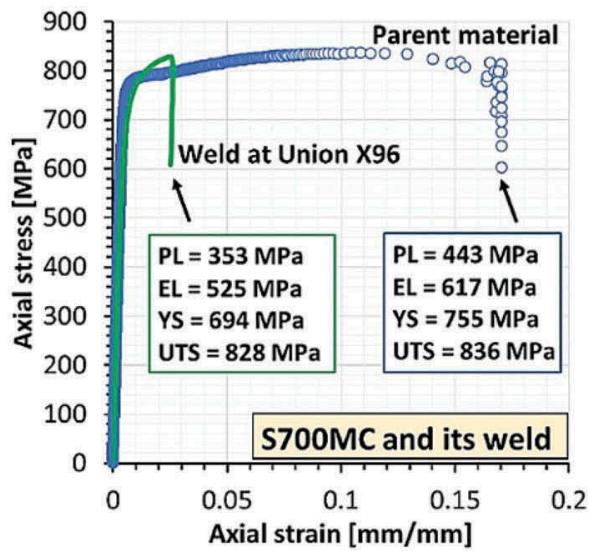

b)

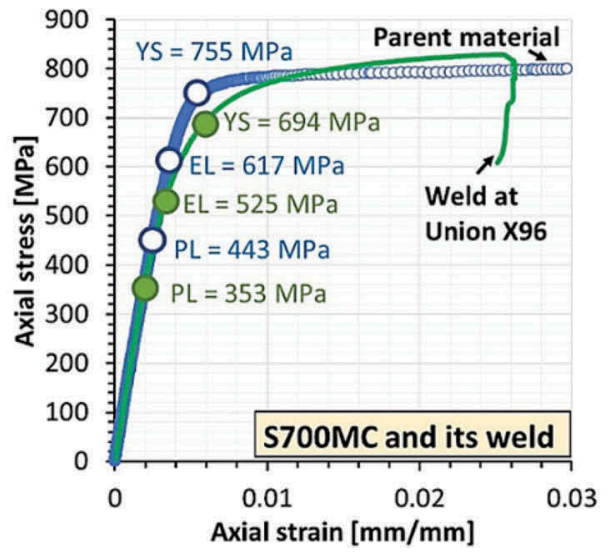

Figure 2. Tensile characteristic of the S700MC as parent material and its welded joint manufactured using the welding wire of Union X96: a) general view with mechanical parameters, b) at magnification on elastic and elastic-plastic sections with selected mechanical parameters.

Table 7. Mechanical parameters of S700MC steel at different control signals: displacement, strain and stress.

\begin{tabular}{lllll}
\hline Velocity & $\begin{array}{l}\text { Proportional } \\
\text { limit[MPa] }\end{array}$ & $\begin{array}{l}\text { Elastic limit } \\
{[\mathrm{MPa}]}\end{array}$ & $\begin{array}{l}\text { Yield stress } \\
{[\mathrm{MPa}]}\end{array}$ & $\begin{array}{l}\text { Ultimate tensile strength } \\
{[\mathrm{MPa}]}\end{array}$ \\
\hline $1 \mathrm{~mm} / \mathrm{min}$ & 463 & 648 & 735 & 850 \\
$0.08 \mathrm{~mm} / \mathrm{mm}$ & 462 & 634 & 765 & 820 \\
$178 \mathrm{MPa} / \mathrm{min}$ & 456 & 628 & 757 & 836 \\
$\begin{array}{l}\text { Maximal } \\
\text { difference }\end{array}$ & 7 & 20 & 30 & 30 \\
Average value & 460 & 635 & 755 & 831 \\
\hline
\end{tabular}

The weld behavior under fatigue at the value of maximum stress close to selected strength parameters enabled to indicate the number of cycles, showing stress value connected directly 
Table 8. Comparison of mechanical parameters of the S700MC and its weld using percentage values.

Percentage differences between mechanical parameters of the parent material and its weld collected in the tensile test

\begin{tabular}{lllll}
\hline $\begin{array}{l}\text { Proportional limit } \\
{[\%]}\end{array}$ & $\begin{array}{l}\text { Elastic limit } \\
{[\%]}\end{array}$ & $\begin{array}{l}\text { Yield stress } \\
{[\%]}\end{array}$ & $\begin{array}{l}\text { Ultimate tensile strength } \\
{[\%]}\end{array}$ & $\begin{array}{l}\text { Elongation } \\
{[\%]}\end{array}$ \\
\hline 20.3 & 14.9 & 8.1 & 1.0 & 85.6 \\
\hline
\end{tabular}

Table 9. Results from fatigue tests conducted at maximum stress close to UTS ( $828 \mathrm{MPa}$ ), YS (694 MPa), EL (525 MPa) and PL (353 MPa).

\begin{tabular}{llll}
\hline$\sigma_{\max }=800 \mathrm{MPa}$ & $\sigma_{\max }=700 \mathrm{MPa}$ & $\sigma_{\max }=500 \mathrm{MPa}$ & $\sigma_{\max }=400 \mathrm{MPa}$ \\
\hline 23090 & 32163 & 349177 & $2 \times 10^{6}$ \\
\hline
\end{tabular}

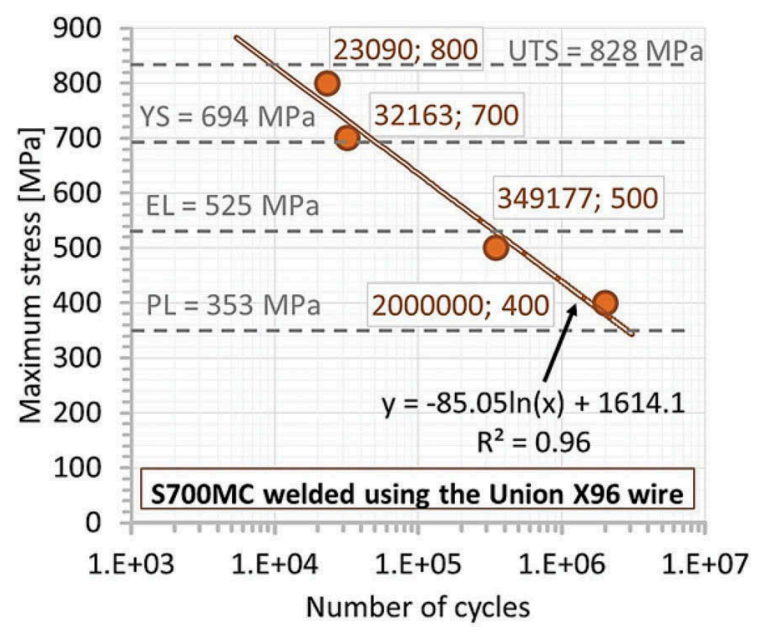

Figure 3. The fatigue test results at the background of the mechanical parameters of the weld.

with fatigue limit, Table 9, Figure 3. Taking these data prediction of fatigue durability of the component made of the S700MC steel welded at the Union X96 wire, especially at stress close to the values of the mechanical parameters selected, is possible to be followed. Nevertheless, for better understanding, the welded joint behavior under fatigue more experiments are needed, capturing Wöhler curve at a greater number of stress level.

\section{SUMMARY}

The weldability of S700MC steel was tested with a large number of different parameters. The result of non-destructive testing limited the possibility of correct welding with all the parameters initially proposed. The bending test result also allowed to reject incorrect welding parameters of S700MC steel. The most appropriate welding parameters depend on a properly selected shielding mixture, the gap between the sheets to be welded and the welding speed. The most 
appropriate parameters (sample W3) correspond to an argon gas mixture containing $18 \% \mathrm{CO}_{2}$ and a welding speed of $350 \mathrm{~mm} / \mathrm{min}$. Strength parameters of the S700MC were almost insensitive on the welding process at the Union X96 wire. This sentence, confirmed by the obtained results, has enabled to indicate this method as an effective joining technique for welding of the S700MC sheet at a thickness up to $5 \mathrm{~mm}$. Fatigue tests have enabled to present the wide range of stress values, which can be directly used in designing and predicting the durability of S700MC welded components, i.e. between proportional limit $353 \mathrm{MPa}$ and ultimate tensile strength $828 \mathrm{MPa}$. The significant feature of the weld of S700MC was also represented by the fatigue limit $400 \mathrm{MPa}$, which supports the engineering point of view because it informs no damages in the weld up to stress value at the mechanical parameter mentioned. Comparing the value of fatigue limit and ultimate tensile strength the following proportion of 0.48 can be proposed for engineers who predict the fatigue limit of welds made of the Strenx MC steel grade capturing results in a form of a tensile curve as well as microstructure similar to data presented.

\section{ACKNOWLEDGMENTS}

The paper is part of the COST project, CA 18223.

\section{REFERENCES}

Lai, C. S., Jia, Y., Dong, Z., Wang, D., Tao, Y., Lai, Q. H., Wong, R. T. K., Zobaa, A. F., Wu, R. \& Lai, L. L. 2020. A Review of Technical Standards for Smart Cities. Clean Technologies, 2, 3, pp. 290-310. (doi:10.3390/cleantechnol2030019).

Connected Vehicles in Smart Cities: The Future of Transportation. Published by interestingengineering. com on 16 November 2018, retrieved on 4 April 2019.

McLaren, D. \& Agyeman, J. 2015. Sharing Cities: A Case for Truly Smart and Sustainable Cities. MIT Press. (ISBN 9780262029728).

Celin, R. \& Burja, J. 2018. Effect of cooling rates on the weld heat affected zone coarse grain microstructure. Metallurgical and Materials Engineering, 24, 1, pp. 37-44. (DOI: https://doi.org/ $10.30544 / 342$ ).

Hobbacher, A. 2016. Recommendations for fatigue design of welded joints and components. International Institute of Welding Collection, Cham, Switzerland: Springer, 27.

Muszyński, T. \& Mikielewicz, D. 2017. Structural optimization of microjet array cooling system. Applied Thermal Engineering, 123, pp. 103-110. (DOI: https://doi.org/10.1016/j.applthermaleng.2017.05.082).

Hadryś D. 2015. Impact load of welds after micro-jet cooling, Archives of Metallurgy and Materials, 60, 4, pp. 2525-2528. (https://doi.org/10.1515/amm-2015-0409).

Węgrzyn, T., Szczucka-Lasota, B., Uściłowska, A., Stanik, Z. \& Piwnik, J. 2019. Validation of parameters selection of welding with micro-jet cooling by using method of fundamental solutions. Engineering Analysis with Boundary Elements, 98, pp. 17-26 (DOI: https://doi.org/10.1016/j.enganabound.2018.09.012).

https://www.worldautosteel.org/steel-basics/automotive-steel-definitions/

Szymczak, T., Brodecki, A., Makowska, K. \& Kowalewski, Z.L. 2019. Tow truck frame made of high strength steel under cyclic loading. Materials Today: Proceedings, 12, 2, pp. 207-212 (DOI: https://doi. org/10.1016/j.matpr.2019.03.115).

SSAB, General Product Description, Data sheet 2008 Strenx 700MC 2017-04-20, 2 pages.

Böhler Welding, Union X 96, Solid wire, low-alloyed, 12.2004, 1 page. 